Genentech, Genzyme, Janssen, Merck, Novartis, Pfizer Inc, Sanofi, UCB, P Mease Grant/research support from: AbbVie, Amgen, Bristol-Myers Squibb, Celgene, Janssen, Eli Lilly, Novartis, Pfizer Inc, Sun, UCB, Consultant for: AbbVie, Amgen, Bristol-Myers Squibb, Celgene, Janssen, Eli Lilly, Novartis, Pfizer Inc, Sun, UCB, Speakers bureau: AbbVie, Amgen, Bristol-Myers Squibb, Celgene, Genentech, Janssen, Novartis, Pfizer Inc, UCB, D. Gladman Grant/research support from: AbbVie, Amgen, Bristol-Myers Squibb, Celgene, Eli Lilly, Janssen, Novartis, Pfizer Inc, UCB, Consultant for: AbbVie, Amgen, Bristol-Myers Squibb, Celgene, Eli Lilly, Janssen, Novartis, Pfizer Inc, UCB, J. Covarrubias-Cobos Grant/research support from: Bristol-Myers Squibb, Eli Lilly, Janssen, Pfizer Inc, D. Fleishaker Shareholder of: Pfizer Inc, Employee of: Pfizer Inc, C. Wang Shareholder of: Pfizer Inc, Employee of: Pfizer Inc, E. Kudlacz Shareholder of: Pfizer Inc, Employee of: Pfizer Inc, S. Menon Shareholder of: Pfizer Inc, Employee of: Pfizer Inc, L. Fallon Shareholder of: Pfizer Inc, Employee of: Pfizer Inc, T. Hendrikx Shareholder of: Pfizer Inc, Employee of: Pfizer Inc, K. Kanik Shareholder of: Pfizer Inc, Employee of: Pfizer Inc

DOI: 10.1136/annrheumdis-2018-eular.3115

\section{SAT0294 ASSOCIATION OF ENTHESITIS WITH ACHIEVEMENT OF NORMAL QUALITY OF LIFE AND CLINICAL RESPONSE IN PATIENTS WITH NON-RADIOGRAPHIC AXIAL SPONDYLOARTHRITIS TREATED WITH ADALIMUMAB}

P.J. Mease ${ }^{1}$, F. Van den Bosch ${ }^{2}$, U. Kiltz ${ }^{3}$, P. Zueger ${ }^{4}$, K. Chen ${ }^{4}$, M. Wu ${ }^{4}$, J. K. Anderson ${ }^{4} .{ }^{1}$ Swedish Medical Center and University of Washington, Seattle, USA; ${ }^{2}$ Ghent University, Ghent, Belgium; ${ }^{3}$ Rheumazentrum Ruhrgebiet, Herne, Germany, ${ }^{4}$ AbbVie, North Chicago, USA

Background: Enthesitis, a key pathology in axial spondyloarthritis (axSpA), has been difficult to treat with conventional therapies and may take longer to resolve than other disease manifestations. It is unknown if failure to attain resolution of enthesitis affects achievement of normal quality of life (QoL) and clinical response.

Objectives: To assess if enthesitis at baseline (BL) and after 12 wks of adalimumab (ADA) treatment in the ABILITY-3 study associates with achieving normal QoL and clinical response in patients (pts) with non-radiographic axSpA (nraxSpA).

Methods: ABILITY-3 enrolled adult pts with nr-axSpA with objective evidence of inflammation (MRI positive or elevated hsCRP), active disease at $\mathrm{BL}$ (ASDAS $\geq 2.1$, BASDAl $\geq 4$, and Patient's Assessment of Total Back Pain score $>4$ ), and an inadequate response to $>2$ NSAIDs. Pts received ADA $40 \mathrm{mg}$ every other wk during a 28-wk open-label lead-in. Pearson's correlation coefficients were used to assess the relationship between total enthesitis count (sum of Maastricht Ankylosing Spondylitis Enthesitis Score [MASES] and plantar fascia enthesitis score) and QoL and disease activity at BL. Multivariable stepwise logistic regression was used to evaluate the relationship between total enthesitis count or enthesitis location and normal QoL (EQ-5D $\geq 0.898$ or SF36 MCS/PCS $\geq 50$ ) and clinical response (ASDAS-ID [ASDAS <1.3], ASAS40, or BASDAI50) at wk 12.

Results: At BL, $74 \%(501 / 673)$ of pts had enthesitis, and mean $(95 \% \mathrm{Cl})$ total enthesitis count was $3.7(3.42,3.98)$. Enthesitis resolved in $39 \%$ (196/501) of pts, and total enthesitis count was $1.9(1.68,2.12)$ at wk 12 of ADA treatment. At BL, total enthesitis count significantly correlated with all QoL and disease activity measures (Table). Each 1-unit increase in BL total enthesitis count was associated with $7 \%$ lower odds of ASDAS-ID (OR [95\% Cl]; 0.93 [0.88, 0.99], $\mathrm{p}=0.018$ ) and $6 \%$ lower odds of BASDAI50 $(0.94[0.89,0.99], p=0.024)$ at wk 12 and was not associated with normal QoL or ASAS40 at wk 12. Total enthesitis count at wk 12 was associated with lower odds of normal QoL and clinical response at wk 12 (Table). Achievement of normal QoL at wk 12 was less likely if pts had BL enthesitis at the posterior $(E Q-5 D \geq 0.898)$ or anterior superior iliac spine (SF36 PCS $>50$ ), and pts with $B L$ enthesitis at the 7 th costochondral joint were less likely to achieve clinical response at wk 12 (Table).
Abstract SAT0294 - Table 1. Association of Total Enthesitis Count With QoL and Disease Activity at BL and Clinical Response at Wk 12

\begin{tabular}{|c|c|c|c|c|}
\hline \multicolumn{5}{|l|}{ Baseline } \\
\hline \multicolumn{2}{|l|}{ Measure } & $\mathbf{n}$ & \multicolumn{2}{|c|}{ Pearson Correlation Coefficient } \\
\hline \multicolumn{2}{|l|}{ EQ-5D } & 672 & \multicolumn{2}{|c|}{$-0.23^{*}$} \\
\hline \multicolumn{2}{|l|}{ SF-36 PCS } & 672 & & $-0.18^{*}$ \\
\hline \multicolumn{2}{|l|}{ SF-36 MCS } & 672 & & $-0.15^{*}$ \\
\hline \multicolumn{2}{|l|}{ BASDAI50 } & 673 & & $0.27^{*}$ \\
\hline \multicolumn{2}{|c|}{ ASDAS } & 673 & & $0.18^{?}$ \\
\hline \multicolumn{2}{|c|}{ Patient Global Assessment } & 673 & & $0.14^{*}$ \\
\hline \multicolumn{2}{|c|}{ Plysician Global Assessment } & 671 & & $0.17^{*}$ \\
\hline \multicolumn{5}{|c|}{ Wk 12} \\
\hline \multicolumn{2}{|l|}{ Measure } & $\mathbf{n}$ & \multicolumn{2}{|c|}{ Odds Ratio $(95 \%$ CI) } \\
\hline \multicolumn{2}{|l|}{$E Q-5 D \geq 0.898$} & 658 & \multicolumn{2}{|c|}{$0.62(0.48,0.78)^{*}$} \\
\hline \multicolumn{2}{|l|}{ SF -36 PCS $\geq 50$} & 658 & \multicolumn{2}{|c|}{$0.70(0.61,0.81)^{*}$} \\
\hline \multicolumn{2}{|l|}{ SF $-36 \mathrm{MCS} \geq 50$} & 658 & \multicolumn{2}{|r|}{$0.85(0.80,0.91)^{*}$} \\
\hline \multicolumn{2}{|l|}{ ASDAS-ID } & 628 & \multicolumn{2}{|r|}{$0.82(0.75,0.91)^{*}$} \\
\hline \multicolumn{2}{|l|}{ ASAS40 } & 632 & \multicolumn{2}{|r|}{$0.82(0.76,0.88)^{*}$} \\
\hline \multicolumn{2}{|l|}{ BASDAI50 } & 632 & \multicolumn{2}{|r|}{$0.74(0.69,0.81)^{*}$} \\
\hline \multicolumn{5}{|c|}{ Enthesitis Location at bascline } \\
\hline Measure at wk 12 & $\mathbf{n}$ & \multicolumn{2}{|c|}{ Location } & Odds Ratio $(95 \% \mathrm{CI})$ \\
\hline$E Q-5 D \geq 0.898$ & 660 & \multicolumn{2}{|c|}{$\begin{array}{l}\text { Posterior superior } \\
\text { iliac spine } L / R\end{array}$} & $0.58(0.34,0.99)^{?}$ \\
\hline SF-36 PCS $\geq 50$ & 660 & \multicolumn{2}{|c|}{$\begin{array}{c}\text { Anterior superior } \\
\text { iliac spine } L / R\end{array}$} & $0.60(0.37,0.96)^{t}$ \\
\hline $\mathrm{SF}-36 \mathrm{MCS} \geq 50$ & 663 & \multicolumn{2}{|c|}{-} & - \\
\hline ASDAS-ID & 630 & \multicolumn{2}{|c|}{$\begin{array}{l}\text { 7th costochondral } \\
\text { joint } L / R\end{array}$} & $0.57(0.36,0.91)^{7}$ \\
\hline ASAS40 & 637 & \multicolumn{2}{|c|}{$\begin{array}{l}\text { 7th costochondral } \\
\text { joint L/R }\end{array}$} & $0.62(0.42,0.91)^{\ddagger}$ \\
\hline BASDAI50 & 634 & \multicolumn{2}{|c|}{$\begin{array}{l}\text { 7th costochondral } \\
\text { joint } L / R\end{array}$} & $0.60(0.40,0.91)^{\frac{7}{7}}$ \\
\hline
\end{tabular}

Locations evaluated included 1st costochondral joint $L / R, 7$ th costochondral joint $L / R$, anterior superior iliac spine $L / R$, posterior superior iliac spine $L / R$, iliac crest $L / R, 5$ th lumbar spinous process, proximal insertion of Achilles tendon $L / R$, and plantar fascia L/R. ASAS40, Assessment of SpondyloArthritis international Society $40 \%$ improvement; ASDAS-ID Assessment of SpondyloArthritis international Society inactive disease; BASDAI, Bath Ankylosing Spondylitis Disease Activity Index; EQ-5D, EuroQol 5 dimension; MCS, mental component summary; PCS, physical component summary, QoL, quality of life; SF-36, short form health survey.

${ }^{\circ} P<0.001 ;{ }^{\dagger} P<0.01 ;{ }^{i} P<0.05$.

Conclusions: $39 \%$ of pts achieved complete resolution of enthesitis after 12 wks of ADA treatment. Total enthesitis count at BL was not associated with normal QoL and inversely associated with clinical response at wk 12. Total enthesitis count at wk 12 was negatively associated with normal QoL and clinical response. Our exploratory analysis suggested possible inverse associations of specific BL enthesitis sites with achievement of normal QoL and clinical response; however, additional research is needed to further define these relationships.

Acknowledgements: AbbVie funded the study and approved the abstract for submission. Medical writing support was provided by Janet Matsuura, PhD, of Complete Publication Solutions, LLC (North Wales, PA) and was funded by AbbVie.

Disclosure of Interest: P. Mease Grant/research support from: AbbVie, Amgen, Bristol-Myers Squibb, Celgene, Janssen, Lilly, Novartis, Pfizer, Sun Pharma, and UCB, Consultant for: AbbVie, Amgen, Bristol-Myers Squibb, Celgene, Janssen, Lilly, Novartis, Pfizer, Sun Pharma, and UCB, Speakers bureau: AbbVie, Amgen, Bristol-Myers Squibb, Celgene, Genentech, Janssen, Novartis, Pfizer, and UCB F. Van den Bosch Grant/research support from: AbbVie, Bristol-Myers Squibb, Celgene, Janssen, Lilly, Merck, Novartis, Pfizer, and UCB, Consultant for: AbbVie, Bristol-Myers Squibb, Celgene, Janssen, Lilly, Merck, Novartis, Pfizer, and UCB, Speakers bureau: AbbVie, Bristol-Myers Squibb, Celgene, Janssen, Lilly, Merck, Novartis, Pfizer, and UCB, U. Kiltz Grant/research support from: Pfizer, Consultant for: AbbVie, Grünenthal, Novartis, and UCB, Speakers bureau: AbbVie, Chugai, Janssen, Lilly, MSD, Novartis, Pfizer, and Roche, P. Zueger Employee of: AbbVie, K. Chen Employee of: AbbVie, M. Wu Employee of: AbbVie, J. Anderson Employee of: AbbVie

DOI: 10.1136/annrheumdis-2018-eular.6797

\section{SAT0295 TOOL FOR THE PRESCRIPTION OF EXERCISE IN SPONDYLOARTHRITIS WITH MULTIMEDIA ANIMATIONS (EJES-3D): PILOT STUDY}

R. Almodóvar ${ }^{1}$, M.T. Florez ${ }^{2}$, P. Zarco ${ }^{1}$, L. Carmona ${ }^{3}$ on behalf of EJES -3D GROUP. ${ }^{1}$ Rheumatology Unit, ${ }^{2}$ RehabilitationUnit, Hospital Universitario Fundación Alcorcon; ${ }^{3}$ Instituto de Salud Musculoesquelética, MADRID, Spain

Background: Exercise is a basic pillar in the management of axial spondyloarthritis (SpA-axe), together with pharmacological treatment ${ }^{1,2}$. Since it has been shown to improve pain, inflammation, mobility, physical and respiratory function. The information provided to the patient on paper on exercises has limitations of understanding. To this must be added the barriers to exercise that patients perceive, such as the lack of adaptation of the exercises according to the SpA phases 